\title{
Physiotherapy Students' Perceptions of Team-Based Learning Using the Team-Based Learning Student Assessment
}

\author{
Renato da Costa Teixeira ${ }^{1}$, Atila Barros Magalhaes ${ }^{1}$, Vera Regina Palacios ${ }^{1} \&$ Madacilina de Melo Teixeira $^{2}$ \\ ${ }^{1}$ Universidade do Estado do Para, Belem, Para, Brasil \\ ${ }^{2}$ Universidade Federal do Para, Belem, Para, Brasil \\ Correspondence: Renato da Costa Teixeira, Programa de Pos-graduacao em Ensino em Saude na Amazonia, \\ Universidade do Estado do Para, Belem, Para, Brasil. E-mail: renatocteixeira@uepa.br
}

\author{
Received: April 25, $2019 \quad$ Accepted: May 20, $2019 \quad$ Online Published: June 13, 2019 \\ doi:10.5539/jel.v8n4p43 URL: https://doi.org/10.5539/jel.v8n4p43
}

\begin{abstract}
According to the National Curricular Guidelines for the undergraduate-level course in physical therapy, the curriculum must promote the training of a generalist, humanist, critical, and reflective professional to develop skills focused on decision-making, communication, leadership, etc. Several methodologies are used in the teaching-learning process; of these, active methodologies are often cited, wherein, contrary to the traditional model of teaching, the roles of the teacher and student are reversed. This study aimed to evaluate students' perception of learning in teams (Team-based learning) as a teaching-learning strategy in the physical therapy undergraduate program of the University of the State of Pará, using the Team-based Learning Student Assessment Instrument (TBL-SAI). A cross-sectional, descriptive study with 21 physical therapy undergraduate students of the UEPA Campus XII was conducted. The TBL-SAI was administered after they participated in an optional course of the respiratory system, wherein the TBL teaching was adopted. The 33 items of the TBL-SAI comprise responses ranging from 1 (I strongly disagree) to 5 (I strongly agree), divided into three subscales: perception of students' accountability, preference for traditional approach or TBL, and students' satisfaction. Average score on the subscales higher than the neutral scores indicated that the students perceived the TBL to be an effective learning tool. The participants reported an overall positive experience using TBL with respect to accountability toward their studies, preference for TBL, and their satisfaction with the method. Future studies should evaluate the impact of TBL on the academic performance and learning ability of undergraduate students of physical therapy.
\end{abstract}

Keywords: active learning, higher education, reflective teaching, physical therapy

\section{Introduction}

In the past few decades, there have been changes in several areas of human knowledge. A 1991 UNESCO document warned about the need for visionary and future-oriented education in the face of "stunning scientific and technological innovations and changes" and that the use of traditional teaching methods did not favor this goal (Roy Singh, 1991).

In a study of university students, it was found that solving exercises as a teaching method could be very effective; however, teachers use explanatory lessons more often than strategies that provide greater participation of students, and similarly, the use of books and papers for student learning is considered the most effective method. Teachers nevertheless still frequently use visual demonstrations with slide projections (Brighenti, Biavatti, \& de Souza, 2015).

Several methodologies are used in the teaching-learning process; of these, active methodologies are often cited, wherein, contrary to the traditional teaching model, the responsible for the learning is of the student and a teacher is a facilitator and mediator of the teaching-learning process (Diesel, Baldez, \& Martins, 2017). One of the main consequences of the active methodologies is the reorientation of the traditional forms of teaching-learning methods and its impact on the mechanisms of producing, developing, standardizing, and disseminating knowledge.

Moran conceptualized active methodologies as teaching strategies which involve effective participation of the students in their learning (Bachic \& Moran, 2018). For Berbel (2011), active methodologies trigger curiosity 
from the moment the students are introduced to the theoretical content, if they present new information that has not been discussed in class yet. When students' contributions are heard and accepted, they become more committed to their studies, as well as become more engaged.

According to the National Curricular Guidelines (NCG) for the physical therapy undergraduate program, the curriculum must provide training to develop a generalist, humanist, critical, and reflective professional; moreover, it must foster the development of skills focused on decision-making, efficient communication, leadership skills, etc (Brasil, 2002). To achieve this, it recommends a collectively-devised educational model centered on a student, so this can be in charge of developing their knowledge and understand the practical importance of what is learned. Teachers are seldom prepared to work from this perspective. The teaching practice in the field of health lacks training in practical performance, as often there is some resistance from the faculty or the students regarding active teaching-learning methodologies (Freitas, Santos, Lima, Miranda, Vasconcelos, \& Nagliate, 2016).

Several models of active methodologies have been used today, among which we can mention Problem Based Learning (PBL), the methodology of the problematization with Maguerez arch, Project Based Learning (PBL) and Task Based Learning (TBL). Task-Based Learning (TBL) is an educational strategy carried out with small groups of students and is a set of sequenced teaching-learning practices, aiming at the development of meaningful learning teams, enabling interaction between students and intercommunication in problem solving (Parmelee, Michaelsen, \& Hudes, 2012).

Task-Based Learning (TBL) is an instructional tactic developed by Larry Michaelsen for management courses in the 1970s that seeks to bring about group benefits and provide a new approach to learning. However, only in 2001 did TBL become widespread, when the US government decided to encourage the inclusion of new teaching methods and finance science educators to approach techniques such as TBL. From then on, TBL has been included in several areas, especially medicine (Parmelee, Michaelsen, Cook, \& Hudes, 2002; Burgess, McGregor, $\&$ Mellis, 2014). Further, studies have pointed out improvements in problem solving and knowledge retention, resulting in better student performance when using TBL in health education (Haidet, O'Malley, \& Richards, 2002; Persky, 2012).

According to Krug et al. (2016) in the TBL each theme is worked in three stages:

a) The first step is Preparation: the student's previous preparation of a task proposed by the teacher outside the classroom.

b) The second is Readiness Assurance: this stage is carried out in the classroom through an individual test, which is later done in a team, with feedback, possibility of appeal and a brief presentation of the teacher.

c) The third step is the Application: and carried out through the execution of several team tasks proposed by the teacher, which involves problem solving and decision making, followed by its presentation and feedback.

For TBL to meet its objectives, some points are fundamental: teams must be permanent; students should be held accountable for the quality of work; teacher feedback must be immediate; the teams must have an odd number to guarantee the tiebreaker in the decisions; to be composed of five to seven students.

Mennenga (2012), whose area of interest involves developing innovative nursing teaching strategies, developed the Team-Based Learning Student Assessment Instrument (TBL-SAI), a valid and reliable instrument that assesses students' perceptions of accountability, preference for traditional classes or TBL, and the level of satisfaction. To date, only one study has been found that examined the use of TBL-SAI in physical therapy students (Livingston, Lundy, \& Harrington, 2014). The remaining studies have examined students from other health programs.

Physical therapy students' acceptance about the type of teaching methodologies used may significantly impact their learning and training as health professionals. This premise is the understanding in which the present study is based. We aimed to shed light on the teaching methods of physical therapy teachers in a public university. Furthermore, the University of the State of Pará (UEPA), the locus of this study, has been undergoing changes in its educational model, transitioning from a traditional methodology to active teaching methodologies.

\section{Methods}

This sample of this cross-sectional, descriptive study included second and third year physical therapy undergraduate students regularly enrolled in the UEPA, Santarém Campus. The students received an oral invitation to participate in a theoretical extra-curricular course about respiratory system.

These students were chosen because they still studied under traditional teaching strategies in their courses. The 
population of both classes was 52 students. The inclusion criteria were second- and third-year students (irrespective of age and gender) who voluntarily agreed to participate in the study.

Forty-three students, who expressed interest in participating, provided their names and contact information, which were used to arrange a meeting during which the date, time, and place of the course sessions were agreed upon. On the day of the meeting, 34 students signed the free consent form, while the others withdrew their participation because of incompatibility with their schedules. Of the 34 students, one student dropped out prior to the start of course, and 12 students missed too many lessons. Finally, 21 participants were included in the analysis which corresponds to about $40 \%$ of the total invited students and $14 \%$ of the total students of the course.

Students opted for these classes as they had already taken the introductory courses with the traditional curriculum, including anatomy, cytology, genetics, biochemistry, and physiology. These students had received only theoretical-practical classes in the classroom and basic science laboratory experience. Thus, it was made sure that none of the participants had curriculum-based experience in professional practice, were doing a compulsory internship, or were exposed to the teaching-learning methodology.

The class was randomly divided into 3 sub-classes with 7 students each, merging second and third graders to give greater diversity, with the same teams remaining in all six sessions, according to Krug's guidelines.

A week after the initial contact, the course in the physiopathology of the respiratory system commenced, and it consisted of six sessions. The classroom meetings were developed as follows: on Monday was sent out the week's script and recommended literature, made available through e-mail to students and through a group created in the WhatsApp application for this purpose. Each script served for the individual study of the students that always occurred before the face-to-face meeting with the researchers, which were held on Fridays took place in the form of TBL sessions, similar to the method proposed by Michaelsen and Sweet (2006).

The thematic of the meetings followed the following scheme: (a) Week 1-Anatomical-respiratory physiology: Structural organization of the respiratory system; Ventilatory mechanics; Pulmonary volumes and capacities; Alveolar ventilation. (b) Week 2-Anatomical-respiratory physiology: Neurochemical control of respiration. Basic properties of gases; Ventilation, perfusion and diffusion; Transport of $\mathrm{O}_{2}$ and $\mathrm{CO}_{2}$; Acid-basic balance; Arterial gasometrial. (c) Week 3-Respiratory Insufficiency: Classification, pathophysiology and clinical-functional correlations. (d) Week 4-Infections of the lower respiratory tract: Epidemiology of respiratory infections; Pneumonia: pathophysiology and clinical-functional correlations; Tuberculosis: pathophysiology and clinical-functional correlations. (e) Week 5-Obstructive pulmonary diseases: Epidemiology Obstructive pulmonary diseases; Asthma (pathophysiology and clinical-functional correlations); Chronic obstructive pulmonary disease (pathophysiology and clinical-functional correlations); Cystic fibrosis (pathophysiology and clinical-functional correlations). (f) Week 6-Restrictive/interstitial lung diseases: Epidemiology Restrictive/interstitial lung diseases; Pneumoconioses (types, pathophysiology and clinical-functional correlations); Sarcoidosis (pathophysiology and clinical-functional correlations). After the face-to-face activity of the sixth week, the TBL-SAI Questionnaire was applied.

The meetings consisted of three steps, as shown in Figure 1 (Bollela, Senger, Tourinho, \& Amaral, 2014). Data were collected from August to October 2016, and each session lasted for 3 hours per week. This was agreed upon during the preliminary meeting with the students, per their availability. 


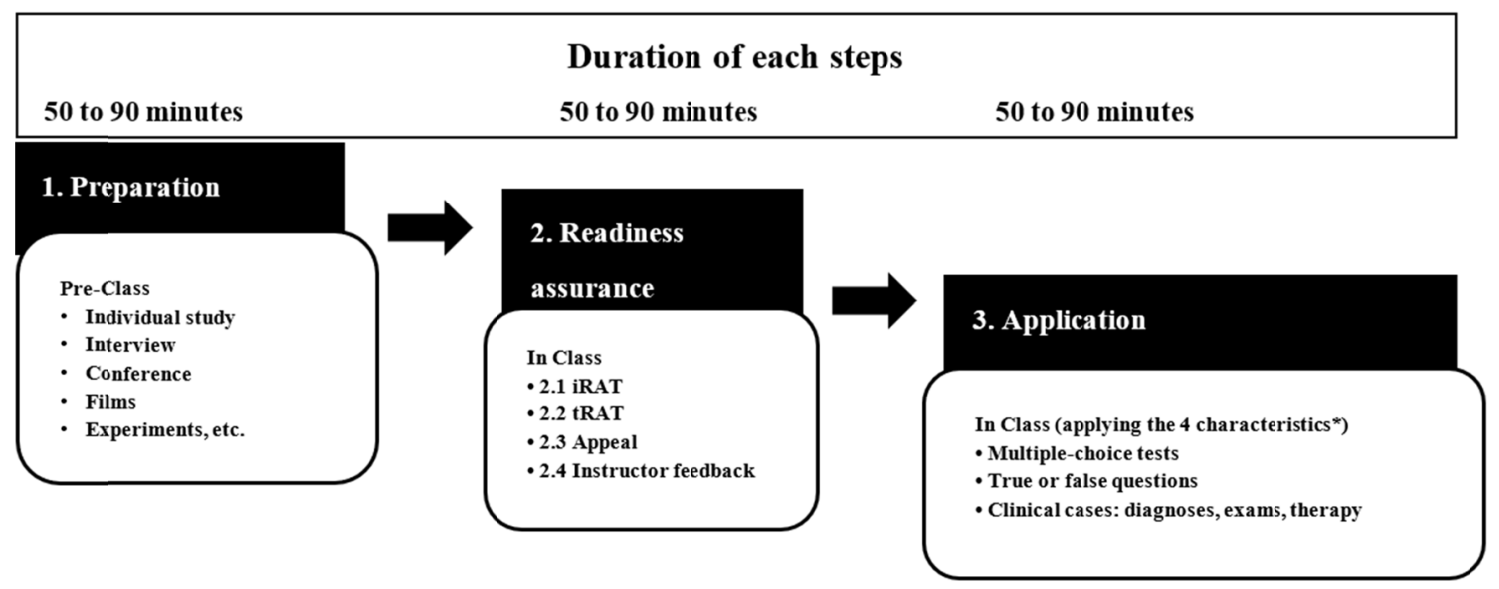

Figure 1. Steps of TBL and their approximate duration

Note. iRAT (individual readiness assurance test); tRAT (team readiness assurance test)

* Significant problem/same problem/specific choice/simultaneous reports

Adapted from Bollela et al. (2014).

After the last TBL session, the TBL-SAI questionnaire was administered. Its use was approved by its author. The TBL-SAI is a 33-item instrument, with each item scored on a Likert-type scale ranging from 1 through 5 (1, strongly disagree; 2, disagree; 3 neither agree nor disagree (neutral); 4, agree; 5 , strongly agree). The items are divided into three subscales: (1) accountability ( 8 items; scores range from 8 to 40); (2) preference for lecture or TBL (16 items; scores range from 16 to 80); (3) student satisfaction (9 items; scores range from 9 to 45). The total TBL-SAI total scores range from 33 to 165 . The neutral scores on each subscale defined by Mennenga ${ }^{14}$ are as follows: accountability, 24; preference for lecture or TBL, 48; student satisfaction, 27; total score, 99. Scores above all the neutral scores were classified as positive attitudes or experiences.

This study was approved by the UEPA Research Ethics Committee-Campus XII (CAAE: 54826716.2.005168/ Opinion: 1.624.33). The study began only after the participants agreed to participate by signing the free consent form, in which the students consented to participate and allowed their anonymized answers to be used for analysis.

\section{Results}

Twenty-one students in the second year $(38.09 \% ; \mathrm{n}=8)$ and third year $(61.90 \% ; \mathrm{n}=13)$ participated in this study; the majority of participants $(85.71 \% ; n=18)$ were females.

All the participants $(n=21)$ completed the questionnaire. The percentages of participants' responses to each of the items are provided in Tables 1,2, and 3.

Table 1. Distribution of responses to the items of the "accountability" subscale

\begin{tabular}{|c|c|c|c|c|c|}
\hline & $\begin{array}{l}\text { I strongly } \\
\text { disagree }(\%)\end{array}$ & $\begin{array}{l}\text { I disagree } \\
(\%)\end{array}$ & $\begin{array}{l}\text { Neither agree nor } \\
\text { disagree }(\%)\end{array}$ & $\begin{array}{l}\text { I agree } \\
(\%)\end{array}$ & $\begin{array}{l}\text { I strongly } \\
\text { agree }(\%)\end{array}$ \\
\hline 1. I spend time studying before class in order to be more prepared. & 0 & 0 & 9.52 & 52.38 & 38.09 \\
\hline 2. I feel I have to prepare for this class in order to do well. & 0 & 0 & 0 & 33.33 & 66.66 \\
\hline 3. I contribute to my team members' learning. & 0 & 0 & 9.52 & 52.38 & 38.09 \\
\hline 4. My contribution to the team is not important.* & 71.42 & 19.04 & 9.52 & 0 & 0 \\
\hline 5. My team members expect me to assist them in their learning. & 0 & 9.52 & 19.04 & 38.09 & 33.33 \\
\hline 6. I am accountable for my team's learning. & 4.76 & 38.09 & 4.76 & 33.33 & 19.04 \\
\hline 7. I am proud of my ability to assist my team in their learning. & 0 & 4.76 & 14.28 & 52.38 & 28.57 \\
\hline 8. I need to contribute to the team's learning. & 0 & 0 & 4.76 & 38.09 & 57.14 \\
\hline
\end{tabular}


Table 2. Distribution of responses to the items of the "preference for lecture or team-based learning" subscale

\begin{tabular}{|c|c|c|c|c|c|}
\hline & $\begin{array}{l}\text { I strongly } \\
\text { disagree }(\%)\end{array}$ & $\begin{array}{l}\text { I disagree } \\
(\%)\end{array}$ & $\begin{array}{l}\text { Neither agree nor } \\
\text { disagree }(\%)\end{array}$ & $\begin{array}{l}\text { I agree } \\
(\%)\end{array}$ & $\begin{array}{l}\text { I strongly } \\
\text { agree }(\%)\end{array}$ \\
\hline $\begin{array}{l}\text { 9. During traditional lectures, I often find myself thinking of } \\
\text { non-related things. }\end{array}$ & 0 & 23.80 & 28.57 & 28.57 & 19.04 \\
\hline 10. I am easily distracted during traditional lectures. & 0 & 19.04 & 42.85 & 28.57 & 9.52 \\
\hline 11. I am easily distracted during team-based learning activities.* & 28.57 & 52.38 & 14.28 & 4.76 & 0 \\
\hline $\begin{array}{l}\text { 12. I am more likely to fall asleep during lectures than during classes } \\
\text { that use team-based learning activities. }\end{array}$ & 9.52 & 19.04 & 4.76 & 38.09 & 28.57 \\
\hline 13. I get bored during team-based learning activities.* & 42.85 & 42.85 & 9.52 & 0 & 4.76 \\
\hline $\begin{array}{l}\text { 14. I talk about non-related things during team-based learning } \\
\text { activities.* }\end{array}$ & 57.14 & 33.33 & 9.52 & 0 & 0 \\
\hline 15. I easily remember what I have learned when working in a team. & 9.52 & 0 & 14.28 & $57.14 \%$ & 19.04 \\
\hline 16. I remember material better when the instructor lectures about it.* & 9.52 & 42.85 & 23.80 & $14.28 \%$ & 9.52 \\
\hline 17. Team-based learning activities help me recall past information. & 0 & 0 & 0 & $38.09 \%$ & 61.90 \\
\hline $\begin{array}{l}\text { 18. It is easier to study for tests when the instructor has lectured on the } \\
\text { material.* }\end{array}$ & 9.52 & 23.80 & 38.09 & 19.04 & 9.52 \\
\hline $\begin{array}{l}\text { 19. I remember information longer when I go over it with team } \\
\text { members during the gRATS (group readiness assurance test) used in } \\
\text { team-based learning. }\end{array}$ & 0 & 0 & 9.52 & 42.85 & 47.61 \\
\hline $\begin{array}{l}\text { 20. I remember material better after the application exercises used in } \\
\text { team-based learning. }\end{array}$ & 0 & 0 & 4.76 & 47.61 & 47.61 \\
\hline 21. I can easily remember material from lectures.* & 9.52 & 9.52 & 52.38 & 28.57 & 0 \\
\hline $\begin{array}{l}\text { 22. After working with my team members, I find it difficult to } \\
\text { remember what we talked about during class.* }\end{array}$ & 38.09 & 52.38 & 4.76 & 4.76 & 0 \\
\hline $\begin{array}{l}\text { 23. I do better on exams when we used team-based learning to cover } \\
\text { the material. }\end{array}$ & 0 & 4.76 & 9.52 & 38.09 & 47.61 \\
\hline $\begin{array}{l}\text { 24. After listening to lecture, I find it difficult to remember what the } \\
\text { instructor talked about during class. }\end{array}$ & 9.52 & 23.80 & 38.09 & 19.04 & 9.52 \\
\hline
\end{tabular}

Note. *Items with inverted scores.

Table 3. Distribution of the responses to the items of the "student satisfaction" subscale

\begin{tabular}{|c|c|c|c|c|c|}
\hline & $\begin{array}{l}\text { I strongly } \\
\text { disagree }(\%)\end{array}$ & $\begin{array}{l}\text { I disagree } \\
(\%)\end{array}$ & $\begin{array}{l}\text { Neither agree nor } \\
\text { disagree }(\%)\end{array}$ & $\begin{array}{l}\text { I agree } \\
(\%)\end{array}$ & $\begin{array}{l}\text { I strongly } \\
\text { agree }(\%)\end{array}$ \\
\hline 25. I enjoy team-based learning activities. & 0 & 0 & 0 & 23.80 & 76.19 \\
\hline 26. I learn better in a team setting. & 0 & 0 & 19.04 & 9.52 & 71.42 \\
\hline $\begin{array}{l}\text { 27. I think team-based learning activities are an effective approach to } \\
\text { learning. }\end{array}$ & 0 & 0 & 0 & 28.57 & 71.42 \\
\hline 28. I do not like to work in teams.* & 57.14 & 19.04 & 14.28 & 4.76 & 4.76 \\
\hline 29. Team-based learning activities are fun. & 0 & 0 & 9.52 & 47.61 & 42.85 \\
\hline 30. Team-based learning activities are a waste of time.* & 76.19 & 19.04 & 0 & 0 & 4.76 \\
\hline 31. I think team-based learning helped me improve my grade. & 0 & 0 & 4.76 & 52.38 & 42.85 \\
\hline 32. I have a positive attitude toward team-based learning activities. & 0 & 0 & 4.76 & 38.09 & 57.14 \\
\hline 33. I have had a good experience with team-based learning. & 0 & 0 & 0 & 33.33 & 66.66 \\
\hline
\end{tabular}

Note. *Items with inverted scores.

Table 4. TBL-SAI score system and total score on each subscale

\begin{tabular}{lllllll}
\hline Category & $\begin{array}{l}\text { Possible } \\
\text { interval }\end{array}$ & $\begin{array}{l}\text { Punctuation } \\
\text { neutral* }\end{array}$ & Mean & $\begin{array}{l}\text { Percentage in } \\
\text { relation to neutral } \\
\text { position (\%) }\end{array}$ & Minimum & Maximum \\
\hline Accountability & $8-40$ & 24 & 22.6 & 35.83 & 24 & 39 \\
Preference for lecture or team-based learning & $16-80$ & 48 & 61.5 & 28.12 & 51 & 80 \\
Student satisfaction & $9-45$ & 27 & 40.6 & 50.37 & 33 & 45 \\
General scale & $33-165$ & 99 & 134.7 & 36.06 & 108 & 164 \\
\hline
\end{tabular}

Note. * Punctuation Neutral is the sum of midpoint rating of subscale scores.

\section{Discussion}

Students perceived TBL as an effective learning tool, as indicated by their mean scores on all scales and the general average being above the neutral score (28.12-50.37\% above the neutral position). The minimum score was equal to or greater than the neutral score on all subscales, as well as the general score, indicating a positive experience with TBL in terms of accountability, preference for a learning mode, and satisfaction. 
Several studies have reported better student performance using TBL compared to traditional learning methods (Wiener, Plass, \& Marz, 2008; Fatmi, Hartling, Hillier, Campbell, \& Oswald, 2013). Mennenga's (2013) study demonstrated the pedagogical significance of TBL; however, more investigations are still required to clearly explain its positive impact on learning outcomes. Many factors are crucial for successful learning outcomes in higher education. One of the most important factors is the integration of students' preferred learning method and the strategies used by the educators (Mangold, 2007).

Many individuals of the current generation of students are part of what is called the millennial generation and they are described as ambitious, stressed, inclusive, confident and optimistic, with a high level of cooperative work ability, and these characteristics of the generation itself influence their learning preferences. For this generation, the old way of teaching centered on the figure of the teacher is not the most indicated because it limits the creativity and criticism of the students (Parmelee, Michaelsen \& Hudes, 2012). According to educational researchers (Billings, 2004; Wilson \& Gerber, 2008), this generation of students expect teachers to facilitate learning and provide immediate feedback. Because of these unique learning preferences, these students pose new challenges to educators, such as the use of new teaching strategies that are engaging, participatory, and relevant. As times are changing, so are educational methodologies to meet students' needs; and TBL is being better accepted by current students, who have different needs than those in earlier times. A previous study (Livingston, Lundy, \& Harrington, 2014) found that doctoral students of physical therapy also reported a positive experience using TBL. Given the learning characteristics and preferences of this generation of graduate students, they concluded that TBL could be used with other academic groups, to improve their academic performance and foster successful learning.

In the abovementioned study, the authors reported scores in line with the conclusion that the students were satisfied with the anatomy classes in TBL. The proportion was $13 \%$ to $24 \%$ above the neutral score that had been proposed by Mennenga (2012). Thus, these students were satisfied with TBL in general anatomy. Although the study course in the present study was optional and the topics were related to physiopathology of the respiratory system, the mean score $(40.6 \pm 3.4)$ on the student satisfaction subscale shows that TBL might be applicable in other situations, thus addressing the previously existing doubt about using this method in basic sciences, wherein the subjects are not purely theoretical.

To date, the study by Livingston, Lundy, and Harrington (2014) has been the only study that examined the use of TBL-SAI on physical therapy students. All other relevant studies (Mennenga, 2012; Mennenga, 2013) examined students studying other health courses, such as nursing. A recent study (Sharmam, Janke, Larson, \& Peter, 2017) evaluated the engagement of students in pharmacotherapy sessions using the TBL-SAI and found positive engagement effects and a higher level of accountability with TBL versus the lecture method.

Other studies also evaluated students' perspectives of TBL, although they used other instruments to assess this. Regardless of the population studied and the instrument used, the students' impression of the method was generally positive across all studies. Moreover, studies that examined the impact of different teaching strategies on learning outcomes showed no differences in students' performance in exams compared to the traditional teaching methodologies. However, in all cases, TBL has been shown to make learning a more fun, pleasant process.

Our findings show that the physical therapy students found the TBL strategy used in this study to be engaging, which helped them become more responsible toward their learning and groups. They seemed to prefer the TBL sessions over the traditional method. They displayed a high level of satisfaction with learning in teams, which was used as a teaching resource during the activities, thus reporting an overall positive experience.

\section{Conclusion}

The reorientation of learning models for physical therapy undergraduate programs in Brazil is a reality, and further research may contribute to improving higher education teaching and supplementing the new curricula. Considering the present situation of implementing the new curriculum of the physical therapy undergraduate program at UEPA, this study makes a significant contribution by providing concrete support for developing and improving teaching strategies, both in this institution as well as in other institutions. It may serve as valid feedback of the impression of active methodologies among the student populations and as a basis for future studies.

Limitations of the study: The small sample of the study, since only $40 \%$ of the invited students accepted to participate; moreover, the study design was not designed to evaluate if this positive impression with the TBL was accompanied by a good performance therefore, although it is not our goal, we can not say whether the students had an effective learning with the method used. 


\section{Acknowledgments}

We thank Dr. Mennenga for providing us with the questionnaire and authorizing its use.

\section{References}

Bachic, L., \& Moran, J. (Org.). (2018). Active methodologies for an innovative education: a theoretical-practical approach. Porto Alegre, Brasil: Penso.

Berbel, N. A. (2011). Active methodologies and the promotion of student autonomy. Semina: Social and Human Sciences. Londrina, 32, 25-40. https://doi.org/10.5433/1679-0383.2011v32n1p25

Billings, D. (2004). Teaching learners from varied generations. The Journal of Continuing Education in Nursing, 35, 104-105. https://doi.org/10.3928/0022-0124-20040501-06

Bollela, V. R., Senger, M.H., Tourinho, F. S., \& Amaral, E. (2014). Team-based learning: from theory to practice. Medicine, Ribeirão Preto, 47, 293-300. https://doi.org/10.11606/issn.2176-7262.v47i3p293-300

Brasil. Ministry of Education. National Council of Education. Higher Education Chamber. Resolution CNE/CES. (2002). Institute National Curricular Guidelines of the Undergraduate Course in Physical Therapy. Retrieved from http://portal.mec.gov.br/cne/arquivos/pdf/CES042002.pdf

Brighenti, J., Biavatti, V. T., \& de Souza, T. R. (2015). Teaching-learning methodologies: an approach under the students' perception. GUAL Revue, Florianópolis, $281-304$. https://doi.org/10.5007/1983-4535.2015v8n3p281

Burgess, A. W., McGregor, D. M., \& Mellis, C. M. (2014). Applying established guidelines to team-based learning programs in medical schools: a systematic review. Academic Medicine, 89, 678-688. https://doi.org/10.1097/ACM.0000000000000162

Diesel, A., Baldez, A. L., \& Martins, S. N. (2017). The principles of active teaching methodologies: a theoretical approach. Thema Revue, Pelotas, 14, 268-288. https://doi.org/10.15536/thema.14.2017.268-288.404

Fatmi, M., Hartling, L., Hillier, T., Campbell, S., \& Oswald, A. E. (2013). The effectiveness of team-based learning on learning outcomes in health professions education: BEME Guide. Medical Teacher, 35, e1608e1624. https://doi.org/10.3109/0142159X.2013.849802

Freitas, D. A., Santos, E. M., Lima, L. V., Miranda, L. N., Vasconcelos, E. L., \& Nagliate, P. D. (2016). Teachers' knowledge about the teaching-learning process and its importance for professional training in health. Interface - Communication, Health, Education. São Paulo, 20, 437-448. https://doi.org/10.1590/1807-57622014.1177

Haidet, P., O’Malley, K. J., \& Richards, B. (2002). An initial experience with "team learning" in medical education. Academic Medicine, 77, 40-44. https://doi.org/10.1097/00001888-200201000-00009

Krug, R. R., Vieira, M. S. M., Maciel, M. V. A., Erdmann, T. R., Vieira, F. C. F., Koch, M. C. et al. (2016). O "Bê-Á-Bá" da Aprendizagem Baseada em Equipe. Revista Brasileira de Educação Médica, 40, $602-610$. https://doi.org/10.1590/1981-52712015v40n4e00452015

Livingston, B., Lundy, M., \& Harrington, S. (2014). Physical therapy students' perceptions of team-based learning in gross anatomy using the Team-Based Learning Student Assessment Instrument. Journal of Educational Evaluation for Health Professions, 11. https://doi.org/10.3352/jeehp.2014.11.1

Mangold, K. (2007). Educating a new generation: teaching baby boomer faculty about millennial students. Nurse Educator, 32, 21-23. https://doi.org/10.1097/00006223-200701000-00007

Mennenga, H. A. (2012). Development and psychometric testing of the team-based learning student assessment instrument. Nurse Educator, 4, 168-172. https://doi.org/10.1097/NNE.0b013e31825a87cc

Mennenga, H. A. (2013). Student engagement and examination performance in a team-based learning course. $J$ Nurse Educator, 52, 475-479. https://doi.org/10.3928/01484834-20130718-04

Michaelsen, L. K., \& Sweet, M. (2008). The essential elements of team-based learning. New Directions for Teaching and Learning, 7-27. https://doi.org/10.1002/t1.330

Parmelee, D., Michaelsen. L. K., Cook. S., \& Hudes. P. D. (2002). Team-based learning: a practical guide: AMEE Guide No. 65. Medical Teacher, 34, e275-e287. https://doi.org/10.3109/0142159X.2012.651179

Persky, A. M. (2012). The impact of team-based learning on a foundational pharmacokinetics course. American Journal of Pharmaceutical Education, 76, 31. https://doi.org/10.5688/ajpe76231 
Roy, S. R. (1991). Education for the twenty-first century: Asia-Pacific perspective. Bangkok, Thailand: UNESCO. Retrieved from https://unesdoc.unesco.org/ark:/48223/pf0000091965

Sharmam, A., Janke, K. K., Larson, A., \& Peter, W. S. (2017). Understanding the early effects of team-based learning on student accountability and engagement using a three session TBL pilot. Currents in Pharmacy Teaching and Learning, 9, 802-807. https://doi.org/10.1016/j.cptl.2017.05.024

Wiener, H., Plass, H., \& Marz, R. (2008). Team-based learning in intensive course format for first-year medical students. Croatian Medical Journal, 50, 69-76. https://doi.org/10.3325/cmj.2009.50.69

Wilson, M., \& Gerber, L. E. (2008). How generational theory can improve teaching: strategies for working with the millennials. Currents in Teaching and Learning, 1, 29-44. Retrieved from https://www.worcester.edu/WorkArea/DownloadAsset.aspx?id=5366

\section{Appendix A}

\section{Team-Based Learning Student Assessment Instrument (TBL-SAI)}

\section{(C) 2010 Heidi A. Mennenga}

This instrument asks you about your experience with team-based learning. There are no right or wrong answers. Please be honest and report your true reaction to each question by circling the number for the response that best describes your answer.

\section{Accountability Subscale}

This subscale assesses student preparation for class and contribution to the team.

The scale for the items is as follows:

$1=$ Strongly Disagree

$2=$ Disagree

$3=$ Neither Disagree or Agree (Neutral)

$4=$ Agree

$5=$ Strongly Agree

\begin{tabular}{llllll}
\hline 1. I spend time studying before class in order to be more prepared. & 1 & 2 & 3 & 4 & 5 \\
2. I feel I have to prepare for this class in order to do well. & 1 & 2 & 3 & 4 & 5 \\
3. I contribute to my team members' learning. & 1 & 2 & 3 & 4 & 5 \\
4. My contribution to the team is not important. & 1 & 2 & 3 & 4 & 5 \\
5. My team members expect me to assist them in their learning. & 1 & 2 & 3 & 4 & 5 \\
6. I am accountable for my team's learning. & 1 & 2 & 3 & 4 & 5 \\
7. I am proud of my ability to assist my team in their learning. & 1 & 2 & 3 & 4 & 5 \\
8. I need to contribute to the team's learning. & 1 & 2 & 3 & 4 & 5 \\
\hline
\end{tabular}

\section{Preference for Lecture or Team-Based Learning Subscale}

This subscale assesses student ability to recall material and student attention level in lecture and team-based learning.

The scale for the items is as follows:

$1=$ Strongly Disagree

$2=$ Disagree

$3=$ Neither Disagree or Agree (Neutral)

$4=$ Agree

$5=$ Strongly Agree

9. During traditional lecture, I often find myself thinking of non-related things.

10. I am easily distracted during traditional lecture.

11. I am easily distracted during team-based learning activities.

12. I am more likely to fall asleep during lecture than during classes that use team-based learning activities.

13. I get bored during team-based learning activities.

\begin{tabular}{lllll}
1 & 2 & 3 & 4 & 5 \\
1 & 2 & 3 & 4 & 5 \\
1 & 2 & 3 & 4 & 5 \\
1 & 2 & 3 & 4 & 5 \\
& & & & \\
1 & 2 & 3 & 4 & 5 \\
\hline
\end{tabular}


14. I talk about non-related things during team-based learning activities.

15. I easily remember what I learn when working in a team.

16. I remember material better when the instructor lectures about it.

17. Team-based learning activities help me recall past information

18. It is easier to study for tests when the instructor has lectured over the material.

19. I remember information longer when I go over it with team members during the GRATS used in team-based learning.

20. I remember material better after the application exercises used in team-based learning.

21 . I can easily remember material from lecture.

22. After working with my team members, I find it difficult to remember what we talked about during class.

23. I do better on exams when we used team-based learning to cover the material.

24. After listening to lecture, I find it difficult to remember what the instructor talked about during class.

\section{Student Satisfaction Subscale}

This subscale assesses student satisfaction with team-based learning.

The scale for the items is as follows:

$$
\begin{aligned}
& 1=\text { Strongly Disagree } \\
& 2=\text { Disagree } \\
& 3=\text { Neither Disagree or Agree (Neutral) } \\
& 4=\text { Agree } \\
& 5=\text { Strongly Agree }
\end{aligned}
$$

\begin{tabular}{llllll}
\hline 25. I enjoy team-based learning activities. & 1 & 2 & 3 & 4 & 5 \\
26. I learn better in a team setting. & 1 & 2 & 3 & 4 & 5 \\
27. I think team-based learning activities are an effective approach to learning. & 1 & 2 & 3 & 4 & 5 \\
28. I do not like to work in teams. & 1 & 2 & 3 & 4 & 5 \\
29. Team-based learning activities are fun. & 1 & 2 & 3 & 4 & 5 \\
30. Team-based learning activities are a waste of time. & 1 & 2 & 3 & 4 & 5 \\
31. I think team-based learning helped me improve my grade. & 1 & 2 & 3 & 4 & 5 \\
32. I have a positive attitude towards team-based learning activities. & 1 & 2 & 3 & 4 & 5 \\
33. I have had a good experience with team-based learning. & 1 & 2 & 3 & 4 & 5 \\
\hline
\end{tabular}

\section{Copyrights}

Copyright for this article is retained by the author, with first publication rights granted to the journal.

This is an open-access article distributed under the terms and conditions of the Creative Commons Attribution license (http://creativecommons.org/licenses/by/4.0/). 